\title{
Co-occurrence of Helicobacter pylori with faecal bacteria in Nairobi river basin: public health implications.
}

\author{
Victor Dinda ${ }^{1}$, Andrew Kimang'a ${ }^{2}$
}

1. Masinde Muliro University of Science and Technology, Medical Laboratory Sciences

2. Jomo Kenyatta Universty of Agriculture \& Technology, Medical Microbiology

\begin{abstract}
:
Introduction: Overwhelming evidence implicates Helicobacter pylori (H. pylori) as an etiologic agent of gastrointestinal diseases including gastric cancer. The mode of transmission of this pathogen remains poorly understood.

Objective: This investigation is to establish the presence of $H$. pylori in the waters of the Nairobi river basin and the predictive value the presence of fecal indicator bacteria would have for $H$. pylori.

Methodology: Physical, chemical and biological assessment of water quality of rivers in Nairobi were carried out using standard methods. H. pylori DNA in water was detected using highly specific primers of glmM gene (294pb).

Results: There was high presence of faecal bacteria in the waters sampled. H. pylori DNA was detected in two domestic wells and one river. The wells were located in two different regions of the water basin but influenced by similar human activities. Conclusion: The high presence of faecal bacteria in the waters sampled did not parallel the $H$. pylori detection in the same waters. H. pylori was detected in the Nairobi river basin, but there was no relationship between the numerical levels of fecal bacteria and $H$. pylori.

Keywords: $H$. pylori, environment, water, coliforms

DOI: http://dx.doi.org/10.4314/ahs.v16i1.24

Cite as: Dinda V, Kimang'a A. Co-occurrence of Helicobacter pylori with faecal bacteria in Nairobi river basin: public health implications. Afri Health Sci. 2016;16(1): 177-182. http:/ / dx.doi.org/10.4314/ahs.v16i1.24
\end{abstract}

\section{Introduction}

More than $50 \%$ of the world's population harbor $H$. pylori in their upper gastrointestinal tract. Infection is more prevalent in developing countries, and incidence is decreasing in Western countries ${ }^{18,3} . H$. pylori exact route of transmission is not known ${ }^{4,12}$. Oral-oral or fecal-oral route is most likely ${ }^{3}$. Consistent with these transmission routes, the bacteria have been isolated from feces, saliva and dental plaque of some infected people3 Transmission occurs mainly within families in developed Nations yet can also be acquired from the community in developing countries ${ }^{6}$. H. pylori may also be transmitted orally by means of fecal matter through the ingestion of waste-tainted water, so a hygienic environment could help decrease the risk of $H$. pylori infection ${ }^{3}$.

\section{Corresponding author: \\ Victor Dinda, \\ Masinde Muliro University of Science \\ and Technology, Medical Laboratory Sciences \\ Email: vicuek2006@yahoo.com}

Previous work has indicated that $H$. pylori, when confronted with unfavourable environmental conditions e.g., a non-enteric environment, will enter into a viable but non-cultivable stage that may or may not maintain virulence ${ }^{9} . H$. pylori, if present in rivers, has probably entered into a stage, precluding the use of culture techniques to accurately determine presence and abundance. This investigation set out to establish the presence of H. pylori in the waters of the Nairobi river basin and to determine the predictive value the presence of faecal indicator bacteria would have for $H$. pylori. The study examined the co-occurrence of faecal bacteria and $H$. pylori through a combination of traditional microbiological analyses and molecular detection using PCR primers glmMf and glmMr that amplify a $294 \mathrm{bp}$ fragment of the gene for the phosphoglucosamine mutase glmM enzyme ${ }^{1}$. These primers are currently the most sensitive and specific primers available for the detection of $H$. pylorit ${ }^{10}$.

\section{Materials and methods}

Study site

The study investigated rivers, wells and boreholes within the Nairobi river basin and neighbouring Thika. Thi$\mathrm{ka}$ is a market town in Central Province, Kenya, $40 \mathrm{~km}$ North-East of Nairobi, and on the Chania River. Both 
Chania and Kiambu rivers form part of the wide Nairobi river basin figure 1. Nairobi River is a river flowing through the Kenyan capital Nairobi. It is the main river of the Nairobi river basin, a complex of several parallel streams flowing eastwards. All of the Nairobi Basin
Rivers join East of Nairobi and meet the Athi River. These rivers are mostly narrow and highly polluted. The main stream, Nairobi River, bounds the Northern city centre. The river is partly canalized. Nairobi River has several tributaries figure 1,2 . Provide GPS or coordinates of study area.

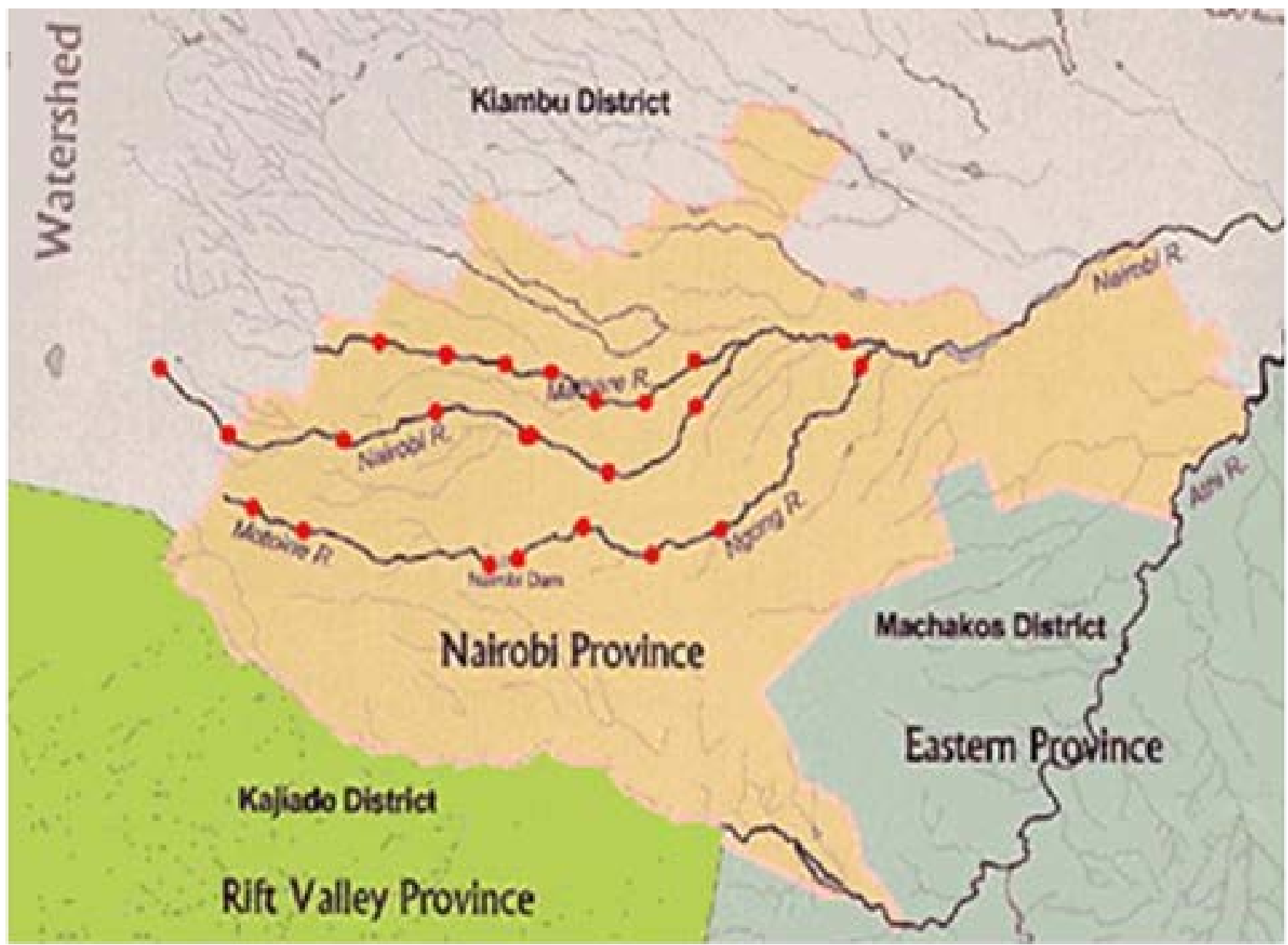

Figure1: A map of the Nairobi River Basin showing the main rivers of the basin (9)

\section{Collection of water samples from rivers}

A sterile collection bottle was immersed, with its mouth closed by the stopper, a foot below the water surface. Facing the direction of the current, the bottle was filled with water by opening the lid, brought to the surface and the stopper replaced.

\section{Collection of samples from wells}

Where the well was fitted with a hand pump or an elec- tric pump, the mouth of the pump was applied with alcohol and allowed to dry. Water was pumped to waste for four to five minutes, before the sample was collected into a sterile bottle. Where there was no pumping machinery, samples were collected directly from the well in a sterilized bottle fitted with some weight at the bottom. Where it was not possible to collect the sample directly into the bottle, samples were obtained by means of a metal jug/ pot. The samples were properly labeled indicating source, date and time of collection. 


\section{Laboratory analyses}

Multiple Tube Fermentation Test for Coliform Bacteria MPN was done according to Cheesbrough ${ }^{5}$ and the MPN was read from the test results by referring to the MPN Table ${ }^{11}$.

\section{Culture and biochemical tests}

Samples were cultured on MacConkey agar. Bacteria were initially identified by their colonial morphology on selective agar and subsequently confirmed using standard biochemical tests.

\section{Extraction of nucleic acids from water}

Total genomic DNA was extracted from water samples according to the method described by Queralt et $\mathrm{al}^{13}$. Efficiency of the extraction protocol for the recovery and detection of $H$. pylori from the environment was carried out as outlined by Voytek et $\mathrm{al}^{17}$. This study anticipated that $H$. pylor in rivers would have entered into a viable but non-cultivable cell stage ${ }^{16}$. Control for the recovery of $H$. pylori DNA from viable but non-cultivable cell stage cells in the environment, was done as per the protocol by Voytek et $\mathrm{al}^{17}$. The sensitivity of each primer set for the detection of $H$. pylori was determined by amplification of serial 10-fold dilutions of purified H. pylori genomic DNA $1 \mu \mathrm{l}$ DNA: $10 \mu \mathrm{l}$ water.

\section{H. pylori detection}

The $H$. pylori status was determined by PCR to detect the $\operatorname{glmM}$ gene using the following primers1; glmM f5'-AAGCTT'TTAGGGGTGTTAGGGGTTT-3', glmM r5'-AAGCTTACTT'TCTAACAT'TAACGC-3', PCR conditions were set as follows, denaturing step of $10 \mathrm{~min}$ at $95^{\circ} \mathrm{C}$, followed by first cycle of $94^{\circ} \mathrm{C}$ for 2 min, annealing at $55^{\circ} \mathrm{C}$ for $1 \mathrm{~min}$, elongation for $1 \mathrm{~min}$ at $72^{\circ} \mathrm{C}$, then a repeat of step 2 for 34 cycles at $94^{\circ} \mathrm{C}$ and a final incubation for $5 \mathrm{~min}$ at $72^{\circ} \mathrm{C}$. The PCR products were analyzed by electrophoresis on a $2 \%$ agarose gel and stained with ethidium bromide.

\section{Results}

One hundred and four water samples were analyzed. These were from 13 study sites, each site was sampled eight times Table 1. The $\mathrm{pH}$ and turbidity were also measured. The data for both parameters were consistent with the type of water analyzed: the lowest $\mathrm{pH} 7.1$ was recorded in water from a fountain and the highest 8.2 in river water. Both values are within the expected range for fresh water between 6.5 and 8.7. The data on suspended solids turbidity depended on the type of water. Most well samples were under 1 nephelometric turbidity units NTU. All the river samples were under 3 NTU Table 2. 
Table 1: Physicochemical parameters from water samples

\begin{tabular}{|c|c|c|c|c|c|c|c|c|}
\hline DATE & $17 / 6 / 2008$ & $18 / 6 / 2008$ & $19 / 6 / 2008$ & $20 / 6 / 2008$ & $21 / 6 / 2008$ & $10 / 7 / 2008$ & $12 / 7 / 2008$ & $15 / 7 / 2008$ \\
\hline \multicolumn{4}{|l|}{ SITE } & \multicolumn{5}{|l|}{$\mathrm{pH}$} \\
\hline WK1 & 7.1 & 7.35 & 7 & 7.12 & 7.1 & 7.2 & 7.23 & 6.9 \\
\hline WK2 & 7.4 & 7.3 & 7.5 & 7.3 & 7.3 & 7.4 & 7.1 & 7.2 \\
\hline WK3 & 7.4 & 7.5 & 7.4 & 7.3 & 7.23 & 7.33 & 7.12 & 7.21 \\
\hline WK4 & 7.3 & 7.4 & 7.32 & 7.6 & 7.45 & 7.43 & 7.46 & 7.55 \\
\hline WT1 & 7.56 & 7.43 & 7.6 & 7.34 & 7.22 & 7.43 & 7.23 & 7.34 \\
\hline WT2 & 7.8 & 7.6 & 7.8 & 7.91 & 7.73 & 7.3 & 8.1 & 7.85 \\
\hline WR1 & 8.1 & 8.1 & 7.7 & 7.9 & 7.8 & 7.5 & 7.9 & 7.78 \\
\hline WR2 & 7.8 & 7.9 & 8.1 & 8.13 & 8.8 & 8.4 & 8.2 & 7.78 \\
\hline WR3 & 7.7 & 7.4 & 7.8 & 7.3 & 7.1 & 7.6 & 7.6 & 7.8 \\
\hline NR & 8.42 & 8.1 & 8.34 & 8.3 & 7.9 & 8.12 & 8.21 & 7.82 \\
\hline NGR & 7.8 & 8.23 & 7.9 & 8.1 & 8.12 & 8.3 & 8.2 & 8.11 \\
\hline $\mathrm{RR}$ & 7.6 & 7.3 & 7.11 & 7.6 & 7.9 & 8.1 & 7.8 & 7.2 \\
\hline MR & 7.21 & 7.2 & 7.11 & 7.2 & 7.1 & 7 & 7.9 & 7.3 \\
\hline \multicolumn{4}{|l|}{ SITE } & \multicolumn{5}{|l|}{ Turbidity } \\
\hline WK1 & 0.98 & 1.4 & 0.72 & 0.69 & 0.8 & 0.76 & 0.87 & 0.8 \\
\hline WK2 & 0.98 & 0.98 & 0.67 & 0.78 & 0.79 & 0.78 & 0.87 & 0.98 \\
\hline WK3 & 0.8 & 1.46 & 0.98 & 0.87 & 0.87 & 0.96 & 0.96 & 1.02 \\
\hline WK4 & 0.98 & 0.8 & 0.95 & 0.94 & 0.98 & 0.98 & 0.87 & 0.89 \\
\hline WT1 & 0.8 & 0.9 & 1.01 & 1.1 & 0.98 & 0.98 & 1.01 & 0.9 \\
\hline WT2 & 0.9 & 0.88 & 0.79 & 0.98 & 0.98 & 0.9 & 0.89 & 0.99 \\
\hline WR1 & 1.72 & 1.72 & 0.78 & 0.99 & 0.98 & 0.78 & 0.9 & 0.96 \\
\hline WR2 & 1.01 & 1.21 & 2.34 & 2.34 & 0.98 & 1.01 & 0.98 & 0.98 \\
\hline WR3 & 0.98 & 0.98 & 0.89 & 1.01 & 1.02 & 0.98 & 0.97 & 0.98 \\
\hline NR & 4.08 & 4.1 & 4.32 & 2.34 & 2.5 & 2.42 & 0.9 & 0.98 \\
\hline NGR & 2.34 & 4.01 & 2.45 & 2.23 & 0.98 & 0.9 & 1.01 & 0.98 \\
\hline $\mathrm{RR}$ & 2.45 & 4.01 & 4.23 & 2.34 & 2.45 & 2.23 & 2.43 & 2.4 \\
\hline \multirow[t]{7}{*}{ MR } & 1.97 & 2.34 & 2.12 & 1.79 & 0.98 & 0.97 & 0.98 & 0.98 \\
\hline & \multicolumn{8}{|l|}{ KEY } \\
\hline & + & Positive & & WK: & Kiambu well & & & \\
\hline & - & Negative & & WT: & Thika Well & & & \\
\hline & NR & Nairobi river & & WR: & Riruta Well & & & \\
\hline & NGR & Ngong river & & MR: & Muthaigariver & & & \\
\hline & $\mathrm{RR}$ & Ruiru river & & & & & & \\
\hline
\end{tabular}

The lowest $\mathrm{pH}$ (7.1) was recorded in water from a fountain and the highest (8.2) in river water. Both values are within the expected range for fresh water between 6.5 and 8.7. The turbidity depended on the type of water. Most well samples were under 1 nephelometric turbidity units (NTU). 
Table 2: Averages of physicochemical parameters from water samples

\begin{tabular}{lll} 
Sample & $\mathrm{pH}$ & Turbidity \\
\hline WK1 & 7.1 & 0.9 \\
WK2 & 7.3 & 0.9 \\
WK3 & 7.3 & 1.0 \\
WK4 & 7.4 & 0.9 \\
WT1 & 7.4 & 1.0 \\
WT2 & 7.8 & 0.9 \\
WR1 & 7.8 & 1.1 \\
WR2 & 8.1 & 1.4 \\
WR3 & 7.5 & 1.0 \\
NR & 8.2 & 2.7 \\
NGR & 8.1 & 1.9 \\
RR & 7.6 & 2.8 \\
MR & 7.3 & 1.5 \\
\hline
\end{tabular}

Key:

WK Kiambu well, NR Nairobi River, RR Ruiru River,MR Muthaiga River, WR Riruta well, WT Thika well, NGR- Ngong River

\section{Discussion}

Presence of $H$. pylori DNA was confirmed at two points of the larger Nairobi river basin, in a public well, in Thika, a satellite town of the city of Nairobi. Thika has both an urban and a rural setup. Much of the surrounding land is agricultural and demand for water has been on the increase here due to the influx of people from the city leading to a rapid urban expansion. Thika is also a home for light industries and this, not only stretches the water demand, but also contributes to the increased pollution. H. pylori DNA was also detected in the Nairobi main river, down east of the flow. The whole of the Nairobi main river channel is highly polluted with both industrial and sewage waste water. The risk factors associated with $H$. pylori infection and transmission are not well understood. Infection is higher in developing than in developed countries ${ }^{14}$. Prevailing Socio economic conditions and sanitation may be associated with the transmission of $H$. pylori ${ }^{8}$. Socioeconomic status is often a surrogate marker for the level of sanitary and hygienic practices, and it is a major variable that frequently correlates with the variation in the prevalence of $H$. pylori infection between different races and ethnic groups $^{19}$. In this study, $H$. pylori was detected in areas inhabited by people of low income status.

Crowding and poor excreta disposal is a factor related to environmental hygiene. This study found that $>90 \%$ of the inhabitants of the areas of detection used outdoor toilet facilities with no connection to the main sewage system. This was in contrast to samples from up market residential areas which were largely negative for $H$. pylori. However all samples were found to be rich in faecal bacteria. Although indoor toilet facilities were available in these areas, the rivers may have picked faecal material a long the way in the course of its flow through low income areas. It has been noted previously that the presence of faecal material near the home is a risk factor for diarrheal disease ${ }^{15}$. It is also possible that good household hygienic practices contribute to the total environmental hygiene.

Results indicate that while $H$. pylori is often found in samples containing fecal indicator bacteria, the presence and abundance of fecal indicator bacteria is not predictive of either $H$. pylori and may not be a telling sign of the H. pylori in water bodies. A study by Kimberly et $\mathrm{al}^{7}$ demonstrated a high degree of variability in the response of fecal indicator organisms to stresses in aquatic environments on all levels of environmental waters. Of noteworthy is the persistence of indicator organisms in sediments, which leads to elevation of their densities and a false indication of recent pollution in the water column after events such as rain storms, construction, or recreational use. Differential survival of indicator organisms has profound implications for microbial source tracking methods that rely on these organisms, particularly those that estimate indicator organism's loadings from various possible contamination sources. In view of the above, it is difficult to tell if 
H. pylori detected in the water bodies was as a result of freshly contaminated water with materials of fecal origin or as a result of $H$. pylori persistence in the environmental waters.

Even though $H$. pylori was detected in the Nairobi river basin, there was no relationship between the numerical levels of fecal bacteria and $H$. pylori. Evidently, the presence of fecal bacteria is of limited value for detection of $H$. pylori in water

\section{References}

1. Bickley J, Owen, R. J, Fraser AG, Pounder RE. Evaluation of the polymerase chain reaction for detecting the urease $\mathrm{C}$ gene of Helicobacter pylori in gastric biopsy samples and dental plaque. J. Med. Microbiol. 1993; 39, 338-344

2. Biosafety News, October/November 2002, CSUD, 2004.

3. Brown LM. "Helicobacter pylori: Epidemiology and Routes of Transmission”. Epidemiol Rev. 2000; 22 2: 283-97. PMID 11218379

4. Cave DR. "Transmission and epidemiology of Helicobacter pylori”. Am. J. Med. 1996; 100 5A: 12S-17S; discussion 17S-18S. PMID 8644777.

5. Cheesbrough M. Medical laboratory manual for tropical countries. 1984; 2: 219 - 220

6. Delport W, van der Merwe SW. "The Transmission of Helicobacter pylori: the Effects of Analysis Method and Study Population on Inference". Best Pract Res Clin Gastroenterol. 2007; 21 2: 215-36. PMID 17382274.

7. Kimberly LA, John EW, Valerie JH. Persistence and Differential Survival of Fecal Indicator Bacteria in Subtropical Waters and Sediments. Applied and Environmental Microbiology. 2005; 71 6: 3041-3048.

8. Klein PD, Graham DY, Gaillour A, Opekun AR, Smith EO. Water source as risk factor for Helicobacter pylori infection in Peruvian children. Gastrointestinal Physiology Working Group. Lancet. 1991; 3378756:1503-6.

9. Krumbiegel P, Lehmann I, Alfreider A, Fritz G. J, Boeckle D, Rolle-Kampczyk U, Richter M, Jorks S, Mu“ ller L, Richter MW, Herbarth O. Helicobacter pylori determination in non-municipal drinking water and epide- miological findings. Isot. Environ. Health Stud. 2004; 401: 75-80.

10. Lu J, Perng, CL, Shyu RY, Chen CH, Lou Q, Chong SK, Lee CH. Comparison of five PCR methods for detection of Helicobacter pylori DNA in gastric tissues. J. Clin.Microbiol. 1999; 373, 772-774.

11. McCrady, MH. The Numerical Interpretation of Fermentation-Tube Results. The Journal of Infectious Diseases, 1915; 17 1: 183-212.

12. Mégraud F. "Transmission of Helicobacter pylori: Faecal-Oral Versus Oral-Oral Route". Aliment. Pharmacol. Ther. 1995; 9 2: 85-91. PMID 8547533.

13. Queralt N, Bartolome R, Araujo R. Detection of Helicobacter pylori DNA in human faeces and water with different levels of faecal pollution in the northeast of Spain. Journal of Applied Microbiology. 2005; 98: 889-895.

14. Shahid A, Mohammad S, Wasim J, Hasnain AS, Saeed, H. Helicobacter pylori Infection: approach of primary care physicians in a developing country. BMC Gastroenterology. 2009 9: 23.

15. VanDerslice J, Briscoe J. Environmental Interventions in Developing Countries: interactions and their implications. [published erratum appears in American Journal of Epidemiology 1422: 227]. American Journal of Epidemiology. 1995; 141:135-144.

16. Velazquez, M. \& Feirtag, J. M. 1999 Helicobacter pylori: characteristics, pathogenicity, etection methods and mode of transmission implicating foods and water. Int. J. Food Microbiol. 53, 95-104.

17. Voytek MA, Ashen JB, Fogarty LR, Kirshtein JD, Landa ER.. Detection of Helicobacter pylori and fecal indicator bacteria in five North American rivers. Journal of Water and Health. 2005; 03.4: 405-422.

18. Yamaoka Y. Helicobacter pylori: Molecular Genetics and Cellular Biology. Caister Academic Pr. 2008; ISBN 1-904455-31-X.

19. Zhannat ZN, Hoda MM, David YG, Almuchambetova A, Machmudova D, Kapsultanova MS, Osato F, Blaine H, Abai Z. Helicobacter Pylori Infection in Kazakhstan: Effect of Water Source and Household Hygiene. American Journal Tropical Medical Hygiene. 2002; 672:201-206 . 